\title{
Impact of Coastal Flooding on Fish Production in Brass, Niger Delta Nigeria, Implication for Coastal Resource Management
}

\author{
Chukwu Okeah $\mathrm{GO}^{1 *}$, Wekpe $\mathrm{VE}^{1}$ and Ikebude $\mathrm{CF}^{2}$ \\ ${ }^{1}$ Department of Geography \& Environmental management, University of Port Harcourt, Nigeria \\ ${ }^{2}$ Department of Civil Engineering, University of Port Harcourt, Nigeria
}

Submission: June 30, 2017; Published: January 25, 2018

*Corresponding author: Chukwu Okeah GO, Department of Geography \& Environmental management, University of Port Harcourt, Nigeria, Tel: 08033408201; Email: gift.chukwuokeah@uniport.edu.ng

\begin{abstract}
In recent times, the deteriorating state of the rivers have begin to gain prominence, this is because there have being a reduction in fish catch and the economy of the fishermen and women who depends on this as their source of livelihood. Due to the fragile nature of the Niger Delta and the turn out of climate change which has lead to excessive rainfall and intense heat, the area has been in so much pains as their only source lo livelihood is been affected. In this study two fishing ports were used and from a water sample analysis it showed that although flooding in the area to an extent affects the quality of water as well as the state of fishes, but the most is the activities of man arising from the use of water bodies as dumpsites for refuse and toilets and oil spills from industrial activities of multinational companies and sand dredging. Therefore the study recommends that government and the private sector should see that within these delicate areas developmental projects that have true bearing on the lives of the people are put in place as to reduce the use of water bodies as the only source of dumping refuse and toilets and that fishermen and women in these areas should be encouraged by way of training and provision of modern fishing equipments as to meet up the demands for fish and improve their own economy.
\end{abstract}

Keywords: Flooding; Costal development; Climate change; Anthropogenic activities

\section{Introduction}

The increasing frequency and sometimes intensity of unusual weather-linked phenomenon as a result of climate change in recent times is evident. The United Nations Framework Convention [1] on climate change is attributed directly or indirectly to human activity, that alters the composition of the global atmosphere, leading to unprecedented weather condition. This in turn overtime affects the food production.

In recent times there is limited understanding of how climate variability currently impacts food systems and associated livelihoods $[2,3]$. This needs to be better understood before assessing the impact of climate change on food security. The impact of long - term trends in climate change, in particular related global warming, is less well - understood in fisheries but is beginning to receive attention.

The Food and Agriculture Organization (FAO) of the United Nations (UN) has developed expertise and experience in rapid appraisal of the impacts of disasters on local fishing communities and aquatic ecosystems and the immediate and longer-term remedial action required. Long-term climate change has important feedback loops to global ocean circulation patterns, sea level rise and changes in ocean salinity all of which affect the biological properties and distribution of species. The
Intergovernmental Panel on Climate Change (IPCC) has linked the rise in sea level to climate change. Between 1960 and 1970, a mean sea level rise of $0.462 \mathrm{~m}$ was recorded along the Nigerian coastal water [4]. Current environmental problems in the coastal area of the country are flooding which comes from the high rainfall, run off from rivers and urban channels and tidal movement and wind [5]. With this problem already common, the issue of sea level rise occasioned by global climate change will exacerbate it. In addition is the potential to cause permanent inundation, beach erosion and salinity. The inundation arising from the rise in sea level will increase problems of floods, intrusion of sea-water into fresh water sources and ecosystems, destroying such stabilizing systems as mangroves, and affecting agriculture, fisheries and general livelihoods [6]. Flooding of low-lying areas in the Niger Delta region has been observed. The phenomenon of flooding is of concern when places important to humans are affected. Floods may be caused by different factors such as rise in stream level, inadequate drainage during and after prolonged precipitation and coastal storms, tides and high waves.

Flooding is one of the most costly and serious hazards to be faced in the use of land resources. Damage is of three categories: 


\section{Water Immersion}

i. The impact of moving water and debris carried by water.

ii. Erosion and depositional activities of streams as their volume and velocity rise and fall.

Floods have continued to be an annual menace to the inhabitants of the Niger Delta Region. The people have been resigned to accepting the situation and also adjusting their activities, agricultural, social or otherwise according to the dictates of the floods about which they have been able to do very little. Some communities in worst affected areas have to build their houses on stilts that rise above the local flood levels. Because of the threat of the floods to property and life, the area has not offered the favourable atmosphere for meaningful investment. Houses in most parts have continued to be temporary structures of mud and thatched roofs, not considered too great an economic loss to the owner in the event of damage by flood or erosion.

The Niger Delta, like any other delta, is built up by deposition of sediments due to the decrease of flow velocity as the in flowing rivers (rivers Niger and Benue), enter a larger and calmer body, in this case, the Atlantic ocean. The resultant topography is that of very gentle slopes leading to numerous criss-crossing distributaries and estuaries with pronounced meanders which have a rich fertile soil with high agricultural potential. But unlike many other deltas the world over, the Niger Delta is about the least utilized with regards to its potentialities for large-scale agricultural development. The factors militating against such development include the difficulty in assess, being mainly by water, and the non-availability of large tracts of flood free land. The Niger Delta can be categorized as the area with Aboh, as the apex, to the Atlantic coast. The main characteristics of the area include the levees of the rivers as the highest land sloping gradually away from the banks to lowlands called back swamps. Such bank swamps are usually filled during the floods as the level of the water rises in river channels, usually leaving only a narrow stretch of land between the riverbanks and back swamps uninundated.

Bayelsa State of which the study area is a local government area is located in the central Niger Delta. So all the aforementioned characteristics of and problems affecting the production of fish in the Niger Delta occur in the state. Flooding is the most serious in the state in comparison with other Niger Delta states.

Fisheries ecosystems and fishing-based livelihoods are subject to a range of climate related variability, from extreme weather events, floods and droughts, through changes in aquatic ecosystem structure and productivity, changing patterns and abundance of fish stocks. Fishery resources are of particular significance in Nigeria as they provide a considerable amount of dietary protein in the country and the sector also serves as a major source of employment and labour for a large proportion of Nigerians in the riverine areas.
Fishing is a major livelihood activity of the people living in the coastal areas of Nigeria. This is because most of their land area is covered by water bodies with very little percentage of the land area suitable for other agricultural production activities such as crop and livestock production. Many households in these coastal areas are most vulnerable to the impact of climate change as a result of their low adaptive capacity to climate change [7]. Recent occurrences of flood have been reported in these coastal areas $[7,8]$. The consequences of flood due to climate change such as loss of fish, change in fish species, erosion of human habitat, and land will have greater impact on the welfare and the livelihood of fishermen most especially in terms of income realized from fishing activities.

As a result of flooding, some species of fishes have migrated to another location while some others died. This leads to low productivity and consequently reduced fish catch and low standard of living. This has also increased the spread of different types of diseases among the fishers and their household which includes malaria, typhoid etc. All these coupled with the problem faced by fishers has led them to adopt different coping strategies.

Francisco et al. [9] conducted a survey related to the perception of the riverine population to flood occurrences at the lower Sao Francisco river municipalities, especially with regards to the 2004 flood. To the riverine population, natural floods were always historically recognized as being positive, with the practice of agriculture on the flooded lands possible and also working as a nursery area for fish, promoting the local biodiversity conservation. With the river discharge regularization throughout the year, a decrease of fish quantity, biodiversity, and waterlogged land farming (marginal lagoon) was reported. Having stated this the interest of the study is to examine coastal flooding and it's effect on fish production in Brass local Government area,along sideidentifying the factors responsible for coastal flooding in the area, identify the extent of flooding, determine the impact of flooding on the economy of fishermen and women in the area and to proffer solution to the menace.

\section{Literature of the Problem}

Water is an indispensable ingredient of life in earth. Its supply is essentially constant and beyond the scope of humans to increase or alter any threat of reduction in availability of lessening of quality of a material so basic to our very lives as water is certain to arouse strong, emotion and deep concerns [10].

Water is a basic constituent of the biotic community. In nature, it occurs in land, below its surface, in the atmosphere and in the biosphere $97 \%$ of the total volume of water available, is in the ocean, $2 \%$ stored in the form of ice-sheels and less than $1 \%$ is available as fresh water. More so, only water in rivers, lake, swamps constitute only $0.36 \%$ of the world fresh water supplies is easily accessible to man and available to use [11]. Although 
man could alter the form and distribution of this usable water or at best improve its quality for better human use the distribution is uneven and fixed.

As population grows, so does demand for fresh water for various uses as mentioned above increases and in turn, population density typically affect the availability and quality of water resource in an area. The problem therefore is not with the global amount of water but its distribution, availability and quality.

According to Caddle in [10], the problem of water lies in four areas, namely, quality, quantity, reliability and financing. Reduced reliability and availability of supply are echoed in a reduced quality of the world's fresh water inventory, increased silt loads of streams, pollution of surface and groundwater supplies and lakes acidified and biologically dead or prematurely filled by siltation and algae growth are evidence of adverse human impact on an indispensable component of the biosphere [12].

Although. human activities are the major causes of water quality degradation. Nature also contaminates water, to a certain degree. Natural water is never pure in the chemical sense. The most basic of these is the role of water as a "universal solvent". Through precipitation and surface run off, minerals, gases, particulate matter are collected down the water bodies and in turn contaminate water. Natural event such as torrential rainfall and horricanes can lead to excessive erosion and landslides, which in turn increases the content of suspended materials in affected rivers. Seasonal overturn of the water in some lake can bring water with little or no dissolved oxygen to the surface.

Flooding is one of the hazardous phenomena associated with human settlements; especially those built lowland, which are generally regarded as floodplains. Floods may result from excessive rainfall, the bursting of dams or in marine environment, tidal influences. Coastal floods may be distinguished from river flood. These differ in cause, length of time of the event and predictability. Flooding brings about deposition of the sediment; the level of levee as well as the river channel may be raised.

The walls of the channels of a flowing river are often steeper than the surrounding landmass. The adjoining floodplain is usually flatter land. The floods that inundate the floodplains represent water that are in excess of the channel's holding capacity. When this occurs, water outside the channel is referred to as floodwater while the river itself is said to be in flood or flood stage. The area of the channel and adjoining flat ground is referred to as floodway. A rare situation is where a large valley has well defined floodplains. When this happens, flood fringe is identified. Inundation of a flood fringe occurs in very high flood situations with a return period of 100 years, in the U.S.A [13].

Perhaps the commoners definition of flood is that of Perkins and Stembridge which defined flood as "when land becomes covered with water". This occurs mostly during rainy season when the level of the river rises, and water covers the land nearby. The rivers are then flooded while the mangrove swamps in the area are flooded when the tide rises.

Defining flood is difficult, partly because floods are complex phenomena and partly because they are viewed differently by different people. Floods occur in many ways, usually in valley bottoms and coastal areas and can be produced by a number of influencing conditions. Their (flood) locations and magnitudes vary considerably and as a result they have marked different effects upon the environment. For most practical purposes and certainly in popular usage a meaningful flood definition will incorporate the notions of "damage" and "inundation".

As might be expected most flood definitions relate to river flood and the one by Chow [14] is not untypical: A flood is a relatively high flow, which overtakes the natural channel provided for the runoff.

In fact many stream channels have been artificially improved upon that the definition of Rost $\mathrm{V}$ et al. [14] is probably most appropriate "A flood is any high stream flow, which overtops the natural of artificial bank of a stream".

However because the banks of a stream vary in height throughout its course, there is no single bank full level above which the river is in flood and below which it is not. In a strictly hydrological sense therefore, a flood may be any relatively high water level or discharge above an arbitrarily selected flood level or flood discharge.

The most cause of flooding is climatological in nature. Keller [15], Akintola [16], and Ward [17] just to mention a few illustrate this assertion in their studies on floods. They all uphold that excessive and prolonged rainfall and the incidence of snowfall are the most universal causes of floods. In other types of floods, climatological factors are partly or indirectly responsible.

Schulz \& Cleaves [18] assert that soil characteristics can also affect flooding with regards to infiltration rate. The portion of rain that sinks below the surface has been estimated to change from about $50 \%$ in humid regions to nearly $100 \%$ in arid regions minus of course soil evaporation. Hence a prolonged input of water can lead to soil beingsaturated resulting in floods as further infiltration becomes impossible [17]. Thus, where rainfall intensity exceeds infiltration capacity, there is increase in the ratio of flood peak discharge resulting in floods. This made a quick flow generation originally propounded by Horton [19] which was though to have universal application, but recent revelations demonstrate that it relates only to conditions of low infiltration and increased human activities [18].

Coates [13] has conveniently divided flood-causing agencies to geologic and human. A comprehensive list of geomorphologic causes include excessive precipitation, snowmelt, ice dams, landslides and glaciers. Of these only two are common in tropical environments like Nigeria. These are excessive precipitation 
and landslides. According to Coates, excessive precipitation is the principal cause of most floods and ultimate cause of almost every flood. The mechanism operates as flows: Stream channels, gullies and rills, are often developed during the fluvial cycle of erosion to hold only the runoff caused during the heaviest rainfall periods. Storms of greater magnitude or intensity may exceed the bank storage and overflow into the floodplain and adjoining terrain.

\section{Analytical Techniques}

Since the study is a survey to determine the effect of coastal flooding on fish production in Brass as well as its effect on the economy of fishermen and women in the area. The researcher made use of secondary data such as rainfall data of the area for a period of 8 years from 2004-2011 which is a determinant of flooding, and a water sample analysis of the river within the period of flooding to see if the quality of the river meets world standard for aquaculture. Among the parameters tested for are; $\mathrm{pH}$, dissolved oxygen, temperature, biological oxygen demand, chemical oxygen demand, total suspended solids, total dissolved solids and turbidity.

Three fishing ports were identified in the study as the sample population amongst which two were randomly selected which are Mbikiri and Igbabele, it was in these two fishing ports that the study was conducted. In the analysis of the data, the multiple regression statistical technique was used to determine the influence of flooding on water quality in the area. Secondly a descriptive statistical analysis was done to ascertain if the quality of the water in the area meets the world standard for aquaculture (Table 1) [21].

Table 1: Yearly Rainfall Amount (Mm), Duration and Intensity (2004 -2011).

\begin{tabular}{|c|c|c|c|}
\hline Year & $\begin{array}{c}\text { Rainfall } \\
\text { Amount }\end{array}$ & $\begin{array}{c}\text { Duration } \\
\text { (hours) }\end{array}$ & $\begin{array}{c}\text { Intensity } \\
\text { (mm/h) }\end{array}$ \\
\hline 2004 & 2567.3 & 1425 & 25.1 \\
\hline 2005 & 2339.7 & 1294.4 & 35.5 \\
\hline 2006 & 2329.4 & 1355.9 & 55.4 \\
\hline 2007 & 2153.5 & 1163.3 & 58.6 \\
\hline 2008 & 2186.2 & 1131.6 & 53.6 \\
\hline 2008 & 1794.1 & 824.7 & 39.7 \\
\hline 2010 & 2153.5 & 1281.8 & 78.2 \\
\hline 2011 & 2186.2 & 1052.1 & 37 \\
\hline
\end{tabular}

Source: extracted from Weli [21].

The table above shows rainfall data and the calculated rainfall intensity for a period of twelve (8) years. The calculated rain fall intensity record shows that there exist variations in the intensity of rainfall amongst the various years with 2010 having the highest intensity of $78.2 \mathrm{~mm} / \mathrm{h}$, followed by 2007 having an intensity of $58.6 \mathrm{~mm} / \mathrm{h}$ and the year 2006 having $55.4 \mathrm{~mm} / \mathrm{h}$. The implication of this is that with the intensity of rainfall in the area been a coastal community which ordinarily is liable to flooding, the area has always experienced flooding but the extent has been determined by the intensity of the rainfall.

\section{Water Sample Analysis Report}

The result of the water samples analysis of the two fishing ports in Brass as the study area is shown below (Table 2)

Table 2: Result of Physiochemical Parameters.

\begin{tabular}{|c|c|c|c|}
\hline S/N & Parameters & Igbabele & Mbikiri \\
\hline 1 & $\mathrm{pH}$ & 5.78 & 6.49 \\
\hline 2 & $\begin{array}{c}\text { Temperature } \\
\left({ }^{\circ} \mathrm{C}\right)\end{array}$ & 26.01 & 26.68 \\
\hline 3 & $\begin{array}{c}\text { Dissolved } \\
\text { Oxygen }(\mathrm{mg} / \mathrm{L})\end{array}$ & 4.04 & 4.45 \\
\hline 4 & $\begin{array}{l}\text { Biological } \\
\text { oxygen demand } \\
(\mathrm{mg} / \mathrm{L})\end{array}$ & 10.98 & 10.2 \\
\hline 5 & $\begin{array}{c}\text { Total } \\
\text { suspended } \\
\text { solid (mg/L) }\end{array}$ & 732 & 780 \\
\hline 6 & $\begin{array}{l}\text { Chemical } \\
\text { oxygen demand } \\
(\mathrm{mg} / \mathrm{L})\end{array}$ & 14 & 14.56 \\
\hline 7 & $\begin{array}{l}\text { Total dissolved } \\
\text { solids (mg/L) }\end{array}$ & 2040 & 3050 \\
\hline 8 & $\begin{array}{l}\text { Turbidity } \\
\text { (NTU) }\end{array}$ & 128.03 & 130.31 \\
\hline
\end{tabular}

In this section the multiple regression statistical technique is used to determine the influence of flooding on the water quality of the two fishing ports, using the equation;

$$
\mathrm{y}=\mathrm{a}+\mathrm{b} 1 \mathrm{x} 1+\mathrm{b} 2 \mathrm{x} 2++\mathrm{e} \ldots \ldots \ldots . . \quad \text { (Equation1) }
$$

where;

$\mathrm{Y}=$ flooding (rainfall intensity)

$\mathrm{a}=$ regression constant

b1-b2 = regression co-efficient

$\mathrm{X} 1$ = water quality parameters for Igbabele

$\mathrm{X} 2$ = water quality parameters for Mbikiri

$\mathrm{e}=$ error term

This is because there is an interplay within the various parameters, their extent of relationship especially as it concerns flooding. That is, to ascertain if water quality parameters of the two fishing ports is influenced by flooding in the area. However, from the data generated the mean flooding (rainfall intensity) was 47.8875 with a standard deviation of 16.82247 (Table 3). Moreso, a table of the various independent variables mean and standard deviations including that of the dependent variable of flooding (rainfall intensity) is shown on the table below. 
Table 3: Summary Statistics of Variables of Study

\begin{tabular}{|c|c|c|c|}
\hline & Mean & Std. Deviation & N \\
\hline Y & 47.8875 & 16.82 & 8 \\
\hline $\mathrm{X} 1$ & 2.88 & 2.232 & 8 \\
\hline $\mathrm{X} 2$ & 502.84 & 1062.76 & 8 \\
\hline
\end{tabular}

A view of the out put of the SPSS computer model among other thingsreveal the correlation matrix to show the relationship between suspended sediment yield to velocity, depth, discharge and bed load.

The Table 4 above displays the correlation matrix of two independent variables of Water quality parameters for Igbabele and Water quality parameters for Mbikiri on the dependent variable of Flood (Rainfall Intensity) in the area.

Table 4: Correlation Matrix for flooding, water quality parameters for Igbabele and water quality parameters for Mbikiri.

\begin{tabular}{|c|c|c|c|}
\hline & $\begin{array}{c}\text { Flood } \\
\text { (Rainfall } \\
\text { Intensity) }\end{array}$ & $\begin{array}{c}\text { Water quality } \\
\text { parameter for } \\
\text { Igbabele. }\end{array}$ & $\begin{array}{c}\text { Water quality } \\
\text { parameter for } \\
\text { Igbabele. }\end{array}$ \\
\hline $\begin{array}{c}\text { Rainfall } \\
\text { Intensity }\end{array}$ & 1.000 & -0.62 & 0.759 \\
\hline $\begin{array}{c}\text { Water quality } \\
\text { parameter for } \\
\text { Igbabele }\end{array}$ & 1.000 & 0.15 \\
\hline $\begin{array}{c}\text { Water quality } \\
\text { parameter for } \\
\text { Mbikiri }\end{array}$ & & & 1.000 \\
\hline
\end{tabular}

From Table 4, it is revealed that a relationship exists between the independent variable of Water quality parameters for Mbikiri and the dependent variable of Flood (Rainfall Intensity). The students " $\mathrm{t}$ " statistic for this correlation is 2.855 and its corresponding table value of 8 degrees of freedom at 0.05 significance level is 2.31 . Hence, this implies that there is no statistically significant relationship between flood (Rainfall Intensity) and Water quality parameter for Mbikiri.

From the Table 4, the water quality parameters for Igbabele has a negative correlation co-efficient of -0.62 with suspended sediment yield. In the same vein, the calculated " $\mathrm{t}$ " statistic for this correlation is 0.199 which is less than the table value at 0.05 significance level and 8 degrees of freedom at 0.05 significance level is 2.31. Hence this implies that there is a statistically significant relationship between flood (Rainfall Intensity) and Water quality parameter for Igbabele.

Conclusively, the implication of the above statement is that flooding influences the water quality of Mbikiri more than that of Igbabele, this is as a result of the type of land use in the area which is high commercial activities and residential land use and the presence of several multi nationals carrying out oil exploration activities in the area. For Igbabele flooding has been described as a major cause of the state of the water quality, arising from surface runoff and anthropogenic actions such as using water bodies as toilets and refuse dumps. Looking at Table 2 above, it is observed that the quality of the water according to each parameter is heavy for Mbikiri more than Igbabele (Table $5)$.

Table 5: Comparison of Water Quality Parameters with W.H.O. Standards for Aquatic Life.

\begin{tabular}{|c|c|c|c|c|}
\hline S/N & Parameters & Igbabele & Mbikiri & WHO Standard \\
\hline 1 & $\mathrm{pH}$ & 5.78 & 6.49 & $6.5-9.0$ \\
\hline 2 & $\begin{array}{c}\text { Temperature } \\
\left({ }^{\circ} \mathrm{C}\right)\end{array}$ & 26.01 & 26.68 & $400 \mathrm{C}$ \\
\hline 3 & $\begin{array}{l}\text { Dissolved } \\
\text { Oxygen } \\
\text { (mg/L) }\end{array}$ & 4.04 & 4.45 & $5 \mathrm{mg} / \mathrm{L}$ \\
\hline 4 & $\begin{array}{c}\text { Biological } \\
\text { oxygen } \\
\text { demand } \\
(\mathrm{mg} / \mathrm{L})\end{array}$ & 10.98 & 10.2 & $59 \mathrm{mg} / \mathrm{L}$ \\
\hline 5 & $\begin{array}{c}\text { Total } \\
\text { suspended } \\
\text { solid (mg/L) }\end{array}$ & 732 & 780 & $>100<220 \mathrm{mg} / \mathrm{L}$ \\
\hline 6 & $\begin{array}{l}\text { Chemical } \\
\text { oxygen } \\
\text { demand } \\
(\mathrm{mg} / \mathrm{L})\end{array}$ & 14 & 14.56 & $100 \mathrm{mg} / \mathrm{L}$ \\
\hline 7 & $\begin{array}{c}\text { Total } \\
\text { dissolved } \\
\text { solids }(\mathrm{mg} / \mathrm{L})\end{array}$ & 2040 & 3050 & $200 \mathrm{mg} / \mathrm{L}$ \\
\hline 8 & $\begin{array}{l}\text { Turbidity } \\
\text { (NTU) }\end{array}$ & 128.03 & 130.31 & $5 \mathrm{NTU}$ \\
\hline
\end{tabular}

From the table above, it is observed that the water quality of the two areas meets the WHO standard with Mbikiri having the highest amount for $\mathrm{pH}$, Temperature $\left({ }^{\circ} \mathrm{C}\right)$, Dissolved Oxygen and Biological oxygen demand while for the other parameters such as Total suspended solid, Chemical oxygen demand, Total dissolved solids and Turbidity, the two areas have amounts of these constituents higher than the WHO standard with Mbikiri also having the highest amount of constituents for each parameter. This then shows that for fishing Igbabele is the best point though some of the parameters do not fall within acceptable standards but is far better than that of Mbikiri.

\section{Conslusion}

In conclusion, arising from the result of the study it is important to state that flooding in its totality may not be responsible for the problem of fishing been experienced in the Niger Delta, but as proofed by the study the effect of man has lead to the deteriorating state of the water quality in our Rivers, in terms of using water bodies as refuse dumps, toilets, avenues for effluent discharge, and more so the activities of oil companies such as oil spill in rivers, and the current boom of sand dredging leading to loss of aquatic lives and reduction in the economic power of fishermen and women in the area.

Hence, the following recommendations are put forward; 
a. There is need to create an agency saddled with the responsibility of coastal zone development, so as to give the area its rightful place noting is fragile nature.

b. Legislations should be put in place and enforced in the interest of the aquatic lives which is fastly declining so as not to go into extinction.

c. Government and the private sector should see that within these delicate areas developmental projects that have true bearing on the lives of the people are put in place as to reduce the use of water bodies as the only source of dumping refuse and toilets.

d. Fishermen and women in these areas should be encouraged by way of training and provision of modern fishing equipments as to meet up the demands for fish and improve their own economy.

\section{References}

1. United Nations Framework Convention on Climate Change (2003) The Ministry of Environment of the Federal Republic of Nigeria, Abuja, Nigeria.

2. Downing TE (2002) Linking sustainable livelihoods and global climate change in vulnerable food systems. Die Erde 133: 363-378.

3. Ziervogel G, Calder R (2003) Climate variability and rural livelihoods: Assessing the impact of seasonal climate forecasts. Area 35(4): 403417

4. Udofa IM, Fajemirokun FA (1978) On a height datum for Nigeria. In: Proceedings of International Symposium on Geodetic Measurements and Computations. Zaria, Ahmadu Bello University, Nigeria, p. 12.

5. Okeke IC (2003) Coastal challenges and the challenges of coastal education in Nigeria. Paper presented to Conek International, Lagos, Nigeria.

6. Okali D, Eleri EO (2004) Climate Change and Nigeria: A Guide for Policy Makers. The publication of the Nigerian Environmental Study Action Team (NEST), Abuja, Nigeria.
7. Gwary D (2008) Climate change, Food security and Nigeria Agriculture. Workshop on the challenges of climate change for Nigeria.

8. Obot E (2008) Climate change and coastal areas in Nigeria. Vulnerability and Adaptation. Workshop on the Challenges of Climate Change for Nigeria.

9. Francisco SRH, Suzete SI, Igor Pinheiro da R, Alysson Santos de J, Renisson Neponuceno de Araujo F, et al. (2009) Environmental Perception of the São Francisco Riverine Population in Regards to Flood Impact. J Hum Ecol 28(1): 37-46.

10. Akpan EN (2010) Spatial variation in water quality along the New Calabar River and its implicationin fisheries production. Unpublished B.sc thesis, University of Port Harcourt, Nigeria.

11. Ayoade JO, Oyebande BC (1983) Water resources. In: Oguntoyinbo JS Areola (Eds.), A Geography of Nigerian Development ( $2^{\text {nd }}$ edn), Ibadan Heinemann, Nigeria.

12. Fellman JD, Getis A, Getis J (2001) Human Geography, Landscapes of Human Activities. McGraw-hill, New York, USA.

13. Coates (1981) Flooding and its Control. Macmillan, London, England.

14. Chow VT (1956) Hydraulic Studies of Floods in United States. McGraw Hill Books Co., New York, USA.

15. Rost V (1968) Summary of Floods in the USA during the 1963 UN Geologic Survey. Supply paper 1830-1833.

16. Keller RE (1933) Environmental Geology. Bell and Hewell Company. USA.

17. Akintola FO (1978) The Hydrological Consequences Urbanization: A case study of Ibadan. In: Sada PO, Oguntoyinbo JS (Eds.), Urbanization processes and Problems. Ibadan Univerity press, Nigeria, pp. 43-49.

18. Ward RT (1978) Floods- A Geographic perspective. Macmillan. London, England.

19. Schultz RT, Cleaves AB (1955) Geology in Engineering. John Wiley and Sons, New York, USA.

20. Horton RE (1933) The Role of Infiltration in the Hydrological Cycle. Trans American Geophysics 14(1): 446-460.

21. Weli VE (2005) Urban flood predictionin Port Harcourt. Unpublished M.sc thesis, University of Port Harcourt, Nigeria.

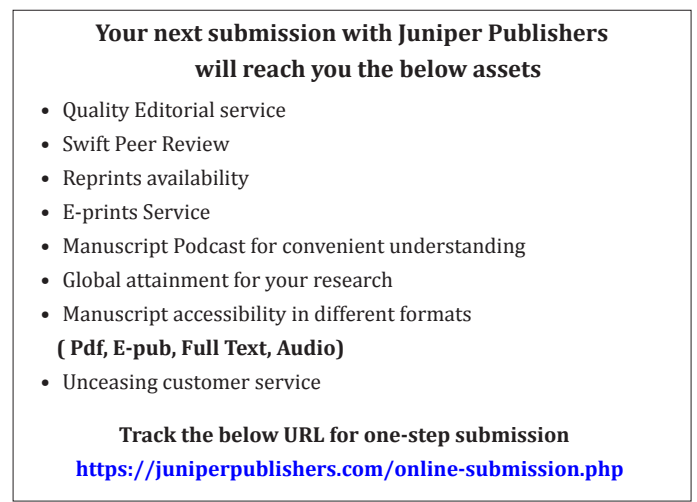

